\title{
Palladium Catalyzed Heck Oxyarylation in Lawsone Derivatives
}

\author{
Lívia C. R. M. da Frota'; Larissa B. Ramalho'; Alcides J. M. da Silva²; Paulo R. R. \\ Costa $^{* 1}$
}

${ }^{1}$ Laboratório de Química Bioorgânica, ${ }^{2}$ Núcleo de Pesquisa de Produtos Naturais, Centro de Ciências da Saúde, BI H, Ilha da Cidade Universitária, Universidade Federal do Rio de Janeiro, Rio de Janeiro, RJ, 22941-590, Brasil .

\section{*prrcosta2011@gmail.com}

Keywords: Heck oxyarylation, lawsone, palladium

\section{INTRODUCTION}

Palladium catalyzed oxyarrylation of chromens, firstly reported by Horino and cols, is a powerful tool to synthesize isoflavonoids. ${ }^{1,2}$ Catalytic versions for this reaction were reported by Larock ${ }^{3}$ and Kiss. ${ }^{4}$ Mechanistic studies on the oxyarylation of olefins by ortho-iodophenols in the presence of silver carbonate as base, as well as the use of microwave irradiation, were recently described by our group. ${ }^{5,6}$ In this work we compared the Heck oxyarylation reaction of Lawsone (1a) and 3-iododerivative (1) with olefin 2 under different conditions (Scheme 1, Table 1).

\section{RESULTS AND DISCUSSION}

We started studying the reaction between $\mathbf{1 b}$ and $\mathbf{2}$, $\mathrm{Ag}_{2} \mathrm{CO}_{3}$ as base ${ }^{2}$ under refluxing acetone.,4 Under thermal condition 3 was obtained in 20\% yield (entry 1) but it was increased to $31 \%$ (entry 2) under microwave irradiation. However, the yield could be improved to up $57 \%$ using pinacolone as solvent, in thermal condition (entry 3). Under microwave irradiation, $50 \%$ was obtained in only $40 \mathrm{~min}$. (entry 4).

Next we move our attention to the possibility of accomplishing this transformation using $\mathbf{1 a}$ as substrate. In this case, a process based on $\mathrm{C}-\mathrm{H}$ activation (direct insertion of $\mathrm{Pd}^{2+}$ on $\mathrm{C}-\mathrm{H}$ bond) was expected.

Scheme 1. Heck oxyarylation of 2 by 1 .<smiles>[X]C1=C(O)C(=O)c2ccccc2C1=O</smiles>

1a, $\mathrm{X}=\mathrm{H}$

1b, $X=I$

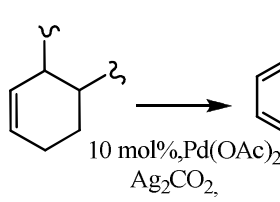

2

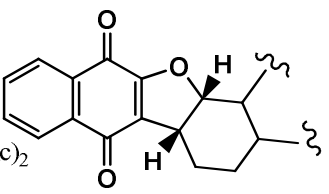

$(+/-)-3$
In the reaction of $\mathbf{1 a}$ with $\mathbf{2}$ under thermal conditions, compound 3 could be obtained in 16\% yield in acetone and could be improved to $34 \%$ in pinacolone. The study of this reaction under microwave irradiation is due in course in our laboratory.

Table 1. Different conditions for Heck oxyarylation between $\mathbf{1}$ and 2.

\begin{tabular}{|c|c|c|c|}
\hline entry & $\mathbf{1}$ & Conditions & $\mathbf{3}(\%)$ \\
\hline 1 & $\mathbf{1 b}$ & $\mathrm{A}$ & 20 \\
\hline 2 & $\mathbf{1 b}$ & $\mathrm{B}$ & 31 \\
\hline 3 & $\mathbf{1 b}$ & $\mathrm{C}$ & 57 \\
\hline 4 & $\mathbf{1 b}$ & $\mathrm{D}$ & 50 \\
\hline 5 & $\mathbf{1 a}$ & $\mathrm{A}$ & 16 \\
\hline 6 & $\mathbf{1 a}$ & $\mathrm{C}$ & 34 \\
\hline
\end{tabular}

Condition $\mathrm{A}: 1.5$ eq. $\mathrm{Ag}_{2} \mathrm{CO}_{3}$, acetone, reflux $\left(60^{\circ} \mathrm{C}\right), 18 \mathrm{~h}$. Condition $\mathrm{B}: 1,5$ eq. $\mathrm{Ag}_{2} \mathrm{CO}_{3}$, acetone, $\mathrm{MW}\left(60^{\circ} \mathrm{C}\right), 40 \mathrm{~min}$. Condition C: 1.5 eq. $\mathrm{Ag}_{2} \mathrm{CO}_{3}$, pinacolone, reflux $\left(110^{\circ} \mathrm{C}\right)$, $18 \mathrm{~h}$. Condition D: 1.5 eq. $\mathrm{Ag}_{2} \mathrm{CO}_{3}$, pinacolone, $\mathrm{MW}\left(10^{\circ} \mathrm{C}\right), 40 \mathrm{~min}$

\section{CONCLUSION}

A new oxyarylation of olefins (2) by 3-iodo-Lawsone (1b) leading to adduct 3 is described, occurring in good chemical yield, under both thermal and microwave irradiation conditions.

Another new procedure is described to preparing 3 from Lawsone 1a, featuring a new $\mathrm{C}-\mathrm{H}$ activation in this quinone. This procedure provides a greater atom economy and is under optimization.

\section{ACKNOWLEDGEMENTS}

To UFRJ, FAPERJ, NPPN, CAPES, FINEP and CNPq.

\section{REFERENCES}

${ }^{1}$ Horino, H.; Inoue, N. Bull. Soc. Jpn. 1971, 44, 3210.

${ }^{2}$ Costa, P.R.R. and cols Bioorg. Med. Chem. 2006, 14, 7962 and cited references.

${ }^{3}$ Emrich, D. E.; Larock, R. C. J. Organomet. Chem. 2004, 689, 3756.

${ }^{4}$ Kiss, L.; Antus, S.; Heterocycl. Commun. 2000, 6, 309.

${ }^{5}$ Costa, P. R. R. J. Organomet. Chem. 2010, 695, 2062.

${ }^{6}$ Costa, P.R.R. and cols Eur. J. Org. Chem., 2011 in press.

${ }^{7}$ Le Bras, J; Muzart, J. chem. Rev., 2011, 111, 1170. 